\section{THE ANXIETIES OF THE SILENT COLONIAL DISCOURSE IN THE SHEIK}

\section{Omar Moumni ${ }^{1}$}

\begin{abstract}
In this paper I examine the Orientalist discourse of the silent movie The Sheik and its contribution to the cultural construction of the Western empire. I argue that despite the orientalizing representation of the Arab "other," this discourse fails to complete its mission and hence problematizes the cultural identity of the sheik. The movie focuses on the sheik as a villainous Arab whose identity, as the film develops, is revealed to be of European origin. This hybridity problematizes the colonial identitarian discourse, reflects cultural anxieties intrinsic to the West and disrupts the colonial dream of conquering and dominating the "other."
\end{abstract}

\section{Orientalizing the Arab in Hollywood's popular silent films}

According to Matthew Bernstein, "Orientalism describes a strand of colonialist discourse in the ideological arsenal of western nations" (1997: 2). It is a system of knowledge about the "other" that leads to the creation of a structured dichotomy between the East and the West. It is what Edward Said calls "imaginative geography" (1979: 49), whose material influence extends beyond the investigation of academic interest to the arena of

\footnotetext{
${ }^{1}$ Lecturer, Faculty of Letters and Human sciences Dhar el-Mehraz- Fez, Sidi Mohammed Ben Abdellah University, Morocco.
}

politics, ideology and the production of culture. Yet, as Bhabha (1994) points out, the discourse of Orientalism is by no means stable nor homogeneous; its ambivalences are symptomatic of many cultural anxieties and contradictions of the West that disrupt its dreams of conquest and domination. The instability of Orientalist discourse is also fruitfully investigated from the perspective of postcolonial feminist theories that, following Said's contention of the gender dimensions of Orientalist discourse that privileges the West as masculine and the Other as feminine, explore the interstices of power and gender relations in their critique of patriarchy. These critical interventions in the homogeneity of Orientalist discourse have enabled a rethinking of the constructions of stereotypes in many areas of cultural productions.

The cinema of the late nineteenth and early twentieth centuries reflects the Orientalist paradigm as well as its contradictions. Through the construction of visual narratives and tropes, identitarian stereotypes of the West and the 'Other' are constructed on the basis of binary relations of good/bad, masculine/feminine, civilized/ barbaric, advanced/primitive, and so forth. These are repeated and become part of the popular cultural imaginary. This process of cultural production is particularly evident in the popular genre of adventure romance set in the desert at the beginning of the twentieth century. It may be said that the popularity of this filmic genre and the influence it exercises on the construction of the Arab stereotype was due to the phenomenal success of The Sheik.

Following its release in 1921, The Sheik won international popularity and paved the way for other similar cinematic exotic 
fantasies. Among the movies we find: The Sheik's Wife (1922), Burning Sands (1922), Tents of Allah (1923), The Arab (1924), The Son of the Sheik (1926), She is a Sheik (1927), The Sheik Steps Out (1937), to name but a few. As Shaheen has argued, these films have been influential as "repetition teaching tool" (2003: 1) for fashioning and perpetuating the Western perception of the Arab as savage and backward. While there is no doubt about the influence of this representation of the 'Other' as well as the visual narrative and tropes-the adventure of a European male/female, his/her captivity, identity twist, followed by a subsequent rescue and revelation, it is also important to be attentive to the ambivalences embedded in the cultural stereotypes that the narrative both reinforces and undermines. In this article, both the stereotypes and their contradictions will be examined through the consideration of the desert as a trope of wildness and adventure, and the ambivalences of the two main protagonists -Diana and the Sheik-and their interactions.

\section{The desert: orientalized geography of wildness and adventure}

The Sheik is a classical silent film that relies on familiar Orientalist stereotypes of the 'Other.' Right from the beginning, the film focuses on the desert as a trope for the imaginary Orientalized space. Recognizable exotic tropes are quickly introduced: palm trees, oasis, camels, veiled figures, horsemen in flowing robes on powerful Arab steeds, sand dunes, minarets and Muslims at prayers. These are succeeded by scenes of Arabs at their simple daily chores of herding, fetching water and food, and children taking their lessons from their teacher with a stick and the desert floor as their "classroom" and learning tools. The film titles make sure how these images of ethnographical and geographical survey are to be read: they make up the exotic world of "peace and flame" where "children of Araby dwell in a happy ignorance that civilization has passed by." The conjunction of "happy ignorance" with "civilization" of course dispels any association of childlike, happy innocence with this imaginary space and insinuates it to be a place of backward barbarity. As the film's unfolds, these attributes are encoded in the film's narrative that focuses on the marriage market taking place in the garden oasis. This is the world of inhumane barbarity where maidens are bought in a marriage market by wealthy merchants, where women are subject to men's sexual desires, where affection and love are replaced by wealth and lust, and where these practices are sanctioned and enshrined as "an ancient custom." The film reinforces these meanings by focusing on the group of maidens as an object of the Arab male gaze, especially on the imploring look of the unfortunate one about to be chosen against her will. In other words, through the desert trope and its narrative of marriage auction, the film defines the Orient to be a site of the Other as barbaric, primitive, and a site of male domination and lust to be feared and kept under surveillance of the West.

As an imaginary site of the Orient, there is of course more to the desert than just a place of barbaric backwardness. According to Said, to the European mind, the Orient was also "a place of romance, exotic being, haunting memories and landscapes, remarkable experiences" (1979:1). In The Sheik, these associations are encoded through the desire of Diana, a young English-rose aristocrat in whose eyes the desert is a site where her desire 
for adventure and independence is to be fulfilled. This aspect of the Orient as a place of allure is further complicated by the transgressive nature of Diana's desire. In the eyes of other colonial women, her planned trip to the desert, accompanied only by an Arab guide, is a "young madcap's wild scheme!" Yet her offense is more than an affront to feminine attributes of modesty and propriety. It is no less than a defiance of Western values of rationality and civilization. These are also encoded in gender terms through the concept of chivalry. Thus, Diana's proud spurning of the her European suitor's avowal of love and marriage proposal, and his gentlemanly offer of protection- " give me the right to go with you"-is an affront to European values of civilization that distinguish European identity from the Arab savagery as in the marriage market. Indeed, as manifest in her subsequent defiance of her brother, her desire is no less than a defiance of European patriarchy on which colonial superiority and power is based. In the white colonial eye, then, her desire is nothing short of a forbidden desire.

Diana's transgression of the white feminine identity and her forbidden desire to discover the Orientalist space is further exacerbated in the scene where she disguises herself as an Arab dancer to gain entry to the casino. Taken over for the exclusive entertainment of the Sheik and his men for one evening, the casino becomes a temporary Orientalist site where white people are forbidden entry. The intended entertainment is a marriage gamble, which, according to the title, is "like a page from the Arabian nights-the marriage gamble where brides are won on the turn of the wheel." The casino is now a mirror image of the desert where the marriage auction is held earlier in the film.
For Diana, that the casino is 'out of bounds' simply stirs her curiosity, desire and defiance. The film shows Diana not only gazing longingly at the female Arab dancer, but also physically moving beyond the European boundaries, marked by the presence of a European male standing at the arch. The film's semantics of the visual space is here elaborate, with Arabian-style niches that function as a space of forbidden desire, on the one hand, and, on the other, arches that double as cultural thresholds and 'keyholes' to the forbidden space of desire beyond.

Once in and now disguised as an Arab dancer, Diana's identity is further destabilized. Seated among the Arab women, she gazes at the dancing girl who is about to be 'won' by a lucky man/gambler. Her reaction is in marked contrast to the leering Arab men, driven wild with sexual excitement. The title here pointedly reads: "to the English girl this marriage fair suggests the slave mart of the barbarous past," and thereby confirm Diana as a European and a woman against the Arabs as the primitive barbarian. Yet, in a series of rapid identity twists that follow, it is precisely Diana's crossdressing that quickly undermines her European identity and superiority. First, her disguise as an Arab woman leads her to be taken as the next 'item.' Next her European identity is recognized by the Sheik, who derisively calls attention to her "pale hands and golden hands of a white woman." Then, standing in front of a bemused male audience, her folding cover now removed by the Sheik to reveal her in an Arab costume, and subject to the Sheik's mocking taunt, she tries to recover her authority as a white woman by putting the Sheik in his place as a "savage": "I want to see the savage who could bar me from this casino." Yet her defiance of the 
Sheik by assuming the Orientalist discourse of power and visibly threatening him with a pistol, is undermined by the Sheik's reversal of the racial stereotype. Mockingly calling himself as a "savage", the Sheik upsets its Orientalist association by his mocking appropriation of European gallantry, "with your permission, the savage will escort you to the door."

If the inconsistencies of the Orientalist discourse are revealed through Diana's desire, they are also disrupted through the ambivalences in the Sheik character. Right from the beginning, he is distinguished from other Arabs through his intervention in the marriage auction by recognizing the young lovers' mutual love and affection and granting them permission to marry. In the casino scene, his identity becomes more unstable, vacillating between lascivious, virile, insolent Arab, and courteous, civilized European. On his arrival at the casino, he appears as a virile Arab in command of other Arab chiefs and who is also at ease with European code of manners and courtesy in the company of Europeans who recognize him as their European-educated equal: "Sheik Ahmed is not a savage; he is a rich tribal prince who was educated in Paris." Yet, unlike his intervention in the earlier marriage scene, here he clearly enjoys the sexual excitement of the spectacle of the dancing Arab girl. In particular, throughout his first encounter with Diana, the courteous chivalrous European gentleman and the insolent Arab who enjoys taunting and humiliating Diana cannot be easily distinguished. Indeed, it is this 'uncanny' mixture that is part of the Sheik's power and enables him to resist Diana and overcome her defiance.

To be sure, there is in both the Sheik and Diana more than just the desire to dominate; there is also mutual attraction. To Diana, the Sheik's arrival at the casino with an enormous entourage of male Arabs is for her an exciting 'exotic' spectacle. Her fascination is increased by her perception of the Sheik's civilized interaction with and acceptance by other Europeans. To the Sheik, he is obviously piqued by Diana's apparent disdain for him, just while he is enjoying charming the Europeans as well as winning their attention and approval. The undercurrent of attraction surfaces in the balcony scene that, according to the title card, "Dawn, with the Arab under the lure of the defiant girl," promises to be full of erotic, even voyeuristic suggestions. First the Sheik climbs up the balcony and gazes at Diana asleep in her bedroom. He then, with a bite, removes a bullet from Diana's pistol-the same one she previously used to threaten him in the casino. The filmic sequence and the 'cuts' are suggestive of a male penetration as much as an erotic dream: the Sheik biting off the bullet-head, Diana sleeping, the Sheik walking away smiling, Diana waking up as if from a dream and half-aware of his presence, to be followed by the Sheik's love serenade of her "pale hands" and Diana dreamily smiling to herself.

Given the ambivalences of the two protagonists, their encounter in the desert turns the Orientalist journey of discovery into a journey of romance. As Shohat says, "the oriental desert is a metaphor of a world ruled by the "out-of-control id", (cited in Semmerling 2006: 37). The film's sequence of abduction and captivity, seduction and attempted rape plays out the Orientalist fantasies of fear and sexual desire, of racial superiority and power through the binarity of virtuous white maidens and lascivious, cruel Arabs. Diana's repeated repulse of the Sheik's 
sexual advances is a characteristic strategy of reinforcing Orientalist stereotypes of the villainous Arab that is to be found in other heroines of similar films such as Angélique in Angélique et le Sultan or Perdicaris in The Wind and the Lion. Indeed, so extreme is the play of desire and fear that, in the attempted rape scene, as Diana is reduced to tearful helplessness by her captivity and futile protest, the sight of her vulnerability miraculously induces pity and a change of heart in the Sheik. While this extraordinary narrative twist may be seen as a prefiguring of, according to Shohat, a subsequent transformation of the Sheik into a civilized European and therefore a confirmation of Western civilizing influence embodied in the feminine vulnerability (1990: 42), it is equally arguable that the Orientalist discourse is here brought to a crisis. The issue is no less than the spectre of miscegenation, the fear and desire of the uncanny and forbidden racial union of white and the Other that both manifests the white domination of the Other while also blurs the racial distinction. The film both enacts and disguises this ambivalence of fear and desire through the Sheik's order to dress Diana in Arab costumes, a symbolic violation of her European identity. This is followed by a softening of Diana's own resistance and, upon hearing the Sheik singing the same song that he had earlier sung, by even her glad realization that the Sheik was the man of her dream. The question here is: how does the film deal with this crisis so that desire may be fulfilled and fear contained?

It is at this crucial point where the film introduces a new character: Raoul de St. Hubert, a romance writer, doctor and friend of the Sheik. His role is that of the benign superego who will both check and heal the rampant id of Diana and the
Sheik. First, he is the voice of conscience and higher values. Upon learning of his expected visit to the Sheik, Diana is ashamed of being seen in an Arab costume by "a man of her world." Her shame is symbolic of her admission of her unacceptable behaviour for a European woman. $\mathrm{He}$ is also an embodiment of sympathy and culture whose romances provide a voice for female desires, inflected as an idealized love. His romance, The Amazing Lovers, is read by Diana, who is carrying it when she hears the Sheik singing the same song, and who clings to it as if for comfort when the Sheik unsympathetically replies, "I always sing when I am happy-when events and things please me," and, to make it worse, horrifies her with the news of his expected visit. The two aspects-sympathy and conscience-come together in an intimate conversation between them when Diana asks: "Does there exist such a man as you have drawn-as tender and faithful as your hero?"

Diana's question is of course provoked by her anger and hurt by the Sheik's cruel treatment of her and his careless response to her dawning love for him. It is the lack of these qualities that make the Sheik come under Raoul's reprimand. It is important to note that, up to now, he is portrayed as an Arab, albeit an ambivalent one. Only through Raoul is his identity as a European revealed. Sheik Ahmed is not an Arab but an English nobleman whose father is an English lord and his mother a Spanish lady. He had been adopted by the ruling Arab Sheik after his parents died in the desert. Raoul reminds him of his white race to convince him that kidnapping and raping women are not among the characteristics of Western culture but rather are restricted to the "Other": "Does the past mean so little to you that you now 
steal white women and make love to them like a savage?" Raoul's reproach of course awakens the Sheik's conscience and he regrets his treatment of Diana. Yet, ironically, Raoul's words serve also to underline the ambivalence of the colonial discourse; it is not an Arab who abducted Diana, but a white man.

To complete the transformation of the Sheik into a European, the film introduces another character: Omair the bandit, whose role is to represent the villainous Arab. The harem becomes the site where stereotypes of the Arab return unqualified, namely male lust and cruelty, and female jealousy. According to Shohat, "The image of the harem allowed the colonial imaginary to play out its own fantasies of sexual domination" (1990: 41). Of course, these fantasies are played out on Diana's body as she is again forced to dress as an Arab woman and is to be raped by Omair to whom she puts up great resistance before she is rescued by the Sheik. Shohat again observes, "The Arab man in these films plays the Id to the western man's Superego. In The Sheik, Valentino acts as the Id only as long as he is known to the spectator as an Arab, but when it is revealed that he is the son of Europeans, he is transformed into a superego figure who nobly risks his life to rescue the English woman from " "real' Arab rapists" (Shohat 1990: 42).

At the end of the movie, Sheik Ahmed fights Omair the bandit and is injured by Omair's slave who hits him on the head. After that, Omair is defeated and Sheik Ahmed, terribly injured, is taken to his tribe. The ending of the movie is complex and problematic. Up to now, although the Sheik's European identity is now known to the audience, to Diana, he is still an Arab. And it is the Sheik as an Arab for whom her love is revealed. It is here where Raoul's role again is crucial. As the Sheik is lying, Diana sits near him and takes his hands. She notices that they are too large for an Arab. She says: "His hand is so large for an Arab," to which and Raoul replies: "He is not an Arab. His father was an Englishmen, his mother a Spaniard." He continues: "Twenty-five years ago the old Sheik Ben Hassan found Ahmed's mother and father deserted by their escort-left to die in the desert. Growing to manhood as an Arab, he was sent to Paris to be educated upon the Sheik's death, returned to the desert to assume leadership of the tribe." The Sheik's European identity is here confirmed and his Arab upbringing is now assimilated as a benevolent substitute for European parenthood.

Through the Sheik's hybridity, then, the film succeeds in both enacting the assimilation of the "other" while at the same time exposes the discursive contradictions and limits of the West. Through the romance of the Sheik's and Diana's love and adventure, the film exposes the gender and racial prejudices of the West. The land of the "Other" is now represented as a space where alternative values of freedom and individual happiness, and gender identities may be envisioned at least as possibilities to be desired.

\section{References}

Bernstein, Matthew and Studlar Gaylyn (eds.). 1997. Visions of the East: Orientalism in Film. New Jersey: Rutgers University Press.

Bhabha, Homi. 1994. The Location of Culture. London: Routledge. 
MANUSYA: Journal of Humanities, Special Issue No. 18, 2009

Said, Edward. 1979. Orientalism. N.Y.:

Random House.

Salvin, David Henry. 2001. Colonial Ccinema and Imperial France 1919. 1939: White Blind Spots, Male Fantasies, Settler Myths. London: The John Hopkins University Press.

Semmerling, Tim Jon. 2006. 'Evil' Arabs in American Popular Film: Orientalist Fear. Austin: University of Texas Press.

Shaheen, G. Jack. 2003. Reel Bad Arabs: How Hollywood Vilifies a People. The American Academy of Political and Social Science 4: 588.

Shohat, Ella. 1990. Gender in Hollywood's Orient. Middle East Report 162: 40-42. 